\title{
Hubungan Asupan Nutrisi dengan Kadar Vitamin D pada Tuberkulosis Anak
}

\author{
Roza Erisma, Gustina Lubis, Finny Fitry Yani \\ Bagian Ilmu Kesehatan Anak Fakultas Kedokteran Universitas Andalas/RSUP Dr M Djamil, Padang
}

Latar belakang. Vitamin D dapat meningkatkan aktivitas antimikrobial makrofag terhadap Mycobacterium tuberculosis. Defisiensi vitamin D diindikasikan sebagai salah satu faktor risiko penyakit tuberkulosis (TB). Kekurangan asupan nutrisi yang mengandung vitamin D dapat memengaruhi kadar vitamin D dalam darah sehingga akan memengaruhi imunitas terhadap infeksi TB.

Tujuan. Mengetahui hubungan asupan nutrisi yang mengandung vitamin D dengan kadar vitamin D darah pada anak yang terinfeksi TB.

Metode. Penelitian cross sectional pada bulan Oktober 2014 sampai Maret 2015 di Poliklinik Anak RS Dr M Djamil dan Puskesmas kota Padang. Subyek penelitian anak usia 1-14 tahun yang kontak serumah dengan TB dewasa BTA positif, dengan hasil tuberculin skin test positif. Asupan vitamin D diperoleh melalui food recall $2 \times 24$ jam dengan standar normal $>600$ International Unit menurut Recommended Dietary Allowance (RDA) dan diolah menggunakan program Nutri-Survey Indonesia. Kadar vitamin D darah berupa $25(\mathrm{OH}) \mathrm{D}$ diukur dengan metode Cheluminescent Immunoassay, kategori nilai normal $>30-50 \mathrm{ng} / \mathrm{mL}$, insufisiensi $>10-30 \mathrm{ng} / \mathrm{mL}$, dan defisiensi $<10 \mathrm{ng} / \mathrm{mL}$.

Hasil. Total subjek penelitian 57 anak. Asupan vitamin D di bawah RDA 54 (94,7\%), 45 (83,3\%) di antaranya mengalami insufisiensi vitamin D dan $9(16,7 \%)$ memiliki kadar vitamin D cukup. Anak dengan asupan vitamin D sesuai RDA 3 (5,3\%), tetapi hanya 1 $(33,3 \%)$ di antaranya memiliki kadar vitamin D darah normal $(\mathrm{p}=0,446)$.

Kesimpulan. Sebagian besar anak yang terinfeksi TB mengalami insufisiensi vitamin D meskipun secara statistik tidak memiliki hubungan yang bermakna dengan asupan nutrisi. Sari Pediatri 2016;18(1):40-4

Kata kunci: asupan nutrisi, kadar vitamin D, infeksi tuberkulosis

\section{Association between Dietary Intake and Vitamin D Level in Children with Tuberculous Infection}

\author{
Roza Erisma, Gustina Lubis, Finny Fitry Yani
}

Background. Vitamin D has already been known for its antimicrobial activity against Mycobacterium tuberculosis and its deficiency indicated as a risk factor of tuberculosis (TB) disease. Lack of dietary intake of vitamin D would compromise the vitamin D status in children with TB infection.

Objective. The aim of the study is to know the association between dietary intake of vitamin D and vitamin D level in children with TB infection.

Method. This cross sectional study was conducted from October 2014 to March 2015 at M Djamil hospital and Community Health Center in Padang. The study subjects were children aged 1-14 years old with household contact of sputum smear-positive adult TB patients and also had positive tuberculin skin test results. Dietary intake of vitamin D was estimated using 2x24 hours Food Recall with normal value > 600 International Unit based on recommended dietary allowance (RDA) and calculated by Indonesian NutriSurvey Program. The vitamin D level $(25(\mathrm{OH}) \mathrm{D})$ was measured using Chemiluminescent Immunoassay and categorized as normal $(>30-50 \mathrm{ng} / \mathrm{mL})$, insufficient $(>10-30 \mathrm{ng} / \mathrm{mL})$ and deficient $(<10 \mathrm{ng} / \mathrm{mL})$.

Result. There were 57 children included in the study. Total of $54(94,7 \%)$ children have vitamin D intake below of RDA. Forty five $(83,3 \%)$ children among them suffered from vitamin D insufficiency and $9(16,7 \%)$ children were in normal level. There were 3 $(5,3 \%)$ children have adequate vitamin D intake but only $1(33,3 \%)$ of them has normal level $(p=0,446)$.

Conclusion. Most of the children with TB infection e suffered from vitamin D insufficiency, although there was no significant statistical association noted with dietary intake. Sari Pediatri 2016;18(1):40-4

Keyword: dietary intake of Vitamin D, vitamin D level, tuberculous infection

Alamat korespondensi: Dr. Roza Erisma. Bagian Ilmu Kesehatan Anak FK-UNAND/RSUP dr M Djamil. Jl. Perintis Kemerdekaan Padang, Sumatera Barat. Tel. +62 (751) 811179. Fax. +62 (751) 811179. E-mail: roza.erisma@yahoo.com 
T Juberkulosis (TB) masih menjadi masalah kesehatan utama di berbagai negara, khususnya di negara berkembang seperti Indonesia. Menurut WHO (World Health Organization), insiden kasus TB pada tahun 2011 mencapai 9 juta dengan angka kematian mencapai 1,4 juta orang pada kasus yang tidak terinfeksi HIV (human immunodeficiency virus) dan sebesar 430000 pada kasus yang terinfeksi HIV, sepertiga di antaranya adalah anak. ${ }^{1-3}$

Sebelum era antibiotik, vitamin $\mathrm{D}$ diketahui sangat berperan dalam pengobatan TB. ${ }^{4}$ Vitamin $\mathrm{D}$ diketahui memiliki peran dalam meningkatkan imunitas tubuh terhadap penyakit infeksi, dengan adanya aktivitas antimikrobial vitamin D pada makrofag. Metabolit aktif vitamin $\mathrm{D}$ berupa $1,25(\mathrm{OH})_{2} \mathrm{D}$ secara in vitro dapat meningkatkan aktivitas antimikrobial, melalui reseptor vitamin $\mathrm{D}$, dengan meningkatkan produksi senyawa peptida (cathelicidin dan defensin) yang akan menginduksi autofagi mycobacterium tuberkulosis pada makrofag. ${ }^{5-8}$ Defisiensi vitamin D diindikasikan sebagai salah satu risiko penyakit TB. Syafii $\mathrm{dkk}^{9}$ menemukan bahwa sebagian besar anak yang sakit TB memiliki kadar vitamin D yang lebih rendah dibanding anak yang tidak sakit TB. Nnoaham dan Clarke, ${ }^{6}$ dalam systematic review dan meta-analisis, menyimpulkan bahwa kadar vitamin $\mathrm{D}$ pada kasus $\mathrm{TB}$ lebih rendah 0,68 SD dibanding individu yang sehat, serta berhubungan dengan risiko terjadinya TB aktif.

Kejadian defisiensi vitamin D diperkirakan mencapai 30\%-50\%, baik pada anak maupun orang dewasa, di berbagai belahan dunia. ${ }^{10}$ Penyebab utama defisiensi vitamin $\mathrm{D}$ adalah kekurangan paparan sinar ultraviolet B (UVB) yang menginduksi sintesis vitamin D di kulit serta kurangnya asupan yang mengandung vitamin D. ${ }^{11,12}$ Wilayah Indonesia mendapatkan paparan sinar matahari yang tinggi, tetapi kejadian TB masih cukup tinggi. Asupan sangat memengaruhi kecukupan nutrisi untuk pertumbuhan yang normal. Asupan vitamin D yang kurang dapat memengaruhi daya imunitas anak terhadap infeksi TB. Berdasarkan hal tersebut, penelitian ini bertujuan untuk mengetahui hubungan asupan nutrisi terhadap kadar vitamin D pada anak yang terinfeksi TB dengan riwayat kontak TB dewasa aktif.

\section{Metode}

Penelitian dilakukan secara cross sectional di Poliklinik Anak RS Dr. M. Djamil dan Puskesmas di kota
Padang sejak Oktober 2014 sampai Maret 2015. Populasi penelitian adalah anak usia 1-14 tahun yang tinggal serumah dengan penderita TB dewasa BTA positif. Sampel penelitian diambil secara consecutive sampling. Kriteria inklusi penelitian adalah anak berusia 1-14 tahun dengan hasil tuberculin skin test (TST) positif dan orangtua menandatangani informed consent. Kriteria eksklusi meliputi anak yang ketahui menderita penyakit metabolik yang berhubungan dengan defisiensi vitamin $\mathrm{D}$, seperti rikets dan diabetes melitus, diketahui menderita tumor atau keganasan lain, menderita infeksi berat, seperti campak, tifoid, HIV, dan sepsis dalam 2 minggu terakhir, menderita penyakit kronis pada ginjal dan hati, atau sedang mendapat terapi obat jangka panjang, seperti steroid dan fenitoin.

Setelah dilakukan pengukuran antropometri, dilakukan pemeriksaan kadar vitamin $\mathrm{D}$ darah berupa 25-(OH)-D plasma dengan metode cheluminescent immunoassay (CLIA). Data konsumsi asupan nutrisi yang mengandung vitamin $\mathrm{D}$, termasuk suplemen multivitamin yang dikonsumsi anak, diperoleh melalui food recall $2 \times 24$ jam (hari libur dan hari biasa). Kandungan vitamin $\mathrm{D}$ dalam asupan diolah menggunakan program Nutri-Survei Indonesia dan diambil rerata asupan per hari dalam satuan international unit (IU). Kategori kecukupan asupan vitamin $\mathrm{D}$ diukur berdasarkan recommended dietary allowance (RDA) dengan batasan nilai normal untuk anak usia $>1$ tahun $>600 \mathrm{IU} /$ hari. Data deskriptif ditampilkan dalam tabel karakteristik subjek penelitian. Analisis statistik dilakukan dengan program SPSS melalui uji Fisher dan $t$-test $(\mathrm{p}<0,05)$.

\section{Hasil}

Total subjek adalah 57 orang anak usia 1-14 tahun yang kontak serumah dengan penderita TB dewasa BTA positif yang menunjukkan hasil pemeriksaan TST positif. Sebagian besar anak yang terinfeksi TB memiliki status gizi baik $(61,4 \%)$. Tidak terdapat anak dengan status gizi buruk ataupun gizi lebih (Tabel 1).

Rerata asupan vitamin D per hari pada anak perempuan lebih besar dibanding anak laki-laki $(\mathrm{p}=0,13)$. Rerata asupan vitamin $\mathrm{D}$ pada anak dengan status gizi baik lebih banyak dibanding dengan gizi kurang $(\mathrm{p}=0,53)$. Namun, secara statistik perbedaan tersebut tidak bermakna (Tabel 2). Sebagian besar 
anak $(83,3 \%)$ yang kurang mendapat vitamin D sesuai RDA mengalami insufisiensi vitamin D dibandingkan dengan anak yang cukup mendapat vitamin D, walaupun secara statistik tidak bermakna (Tabel 3).

Tabel 1.Karakteristik subjek penelitian

\begin{tabular}{lcc}
\hline Karakteristik & $\mathrm{n}$ & $\%$ \\
\hline Jenis kelamin & & \\
$\quad$ Laki-laki & 33 & $(57,9)$ \\
Perempuan & 24 & $(42,1)$ \\
Status gizi & & \\
Baik & 35 & $(61,4)$ \\
Kurang & 22 & $(38,6)$ \\
\hline
\end{tabular}

Tabel 2. Rerata kadar vitamin D berdasarkan asupan nutrisi

\begin{tabular}{lccc}
\hline & $\begin{array}{c}\text { Rerata } \pm \text { standar } \\
\text { deviasi (IU) }\end{array}$ & $\mathrm{n}$ & $\mathrm{p}$ \\
\hline Jenis kelamin & & & \\
$\quad$ Laki-laki & $244,7 \pm 171,9$ & 33 & 0,13 \\
$\quad \begin{array}{c}\text { Perempuan } \\
\text { Status gizi }\end{array}$ & $299,7 \pm 179,5$ & 24 & \\
$\quad$ Kurang & $259,5 \pm 160,5$ & 22 & 0,53 \\
$\quad$ Baik & $288,3 \pm 181,4$ & 35 & \\
\hline
\end{tabular}

Tabel 3. Hubungan kadar vitamin D berdasarkan asupan nutrisi dengan kadar vitamin D plasma

\begin{tabular}{lcccccc}
\hline & \multicolumn{3}{c}{ Kadar vitamin D plasma } & \\
\cline { 2 - 3 } Asupan & \multicolumn{2}{c}{ Insufisiensi } & \multicolumn{2}{c}{ Cukup } & $\mathrm{p}$ \\
\cline { 2 - 3 } Vitamin & $\mathrm{n}$ & $\%$ & & $\mathrm{n}$ & $\%$ & \\
\hline & & & & & \\
Kurang & 45 & 83,3 & & 16,7 & 0,446 \\
Cukup & 2 & 66,7 & & 1 & 33,3 & \\
\hline
\end{tabular}

\section{Pembahasan}

Tigapuluh tiga dari 57 orang subjek berusia Balita. Anak usia kurang dari 5 tahun memiliki risiko terinfeksi TB lebih besar karena belum memiliki imunitas selular yang sempurna., ${ }^{2,4}$ Sebagian besar anak $(61,4 \%)$ memiliki status gizi yang baik. Beberapa kepustakaan sebelumnya melaporkan bahwa infeksi TB berkaitan dengan status gizi yang kurang atau buruk. Hal tersebut mengimplikasikan bahwa masih ada faktor lain yang memengaruhi risiko infeksi maupun sakit TB pada anak selain status gizi. Penelitian Tornee $\mathrm{dkk}^{13}$ melaporkan adanya faktor lingkungan, seperti kepadatan dan kurangnya ventilasi rumah sehingga meningkatkan risiko terinfeksi tiga kali lebih besar pada anak yang kontak TB dewasa aktif serumah. Peran kadar vitamin D yang rendah dalam imunitas terhadap kuman $M$. tuberkulosis juga memengaruhi infeksi TB. . $, 8,9,14^{-14}$

Sebagian besar anak (94,7\%) yang terinfeksi TB mendapat asupan vitamin D di bawah RDA dan $83,3 \%$ di antaranya mengalami insufisiensi vitamin D. Kami tidak menemukan anak dengan defisiensi vitamin D. Sebuah telaah sistematik dan meta-analisis oleh Nnoaham dan Clarke ${ }^{6}$ melaporkan bahwa terdapat kadar vitamin D yang rendah pada penderita TB dibanding kontrol. Yamshichikof $\mathrm{dkk}^{15}$ melaporkan bahwa $86 \%$ pasien TB dewasa mengalami insufisensi vitamin D. Kadar vitamin D yang rendah pada anak TB dapat dipengaruhi oleh faktor internal maupun eksternal. Faktor internal, antara lain tingginya pemanfaatan vitamin $\mathrm{D}$ sebagai mekanisme pertahanan tubuh terhadap infeksi kuman $M$. tuberkulosis dan adanya kemungkinan polimorfisme genetik pada reseptor vitamin $\mathrm{D}$ yang memengaruhi sintesis vitamin D. ${ }^{16}$ Faktor eksternal, antara lain asupan nutrisi vitamin $\mathrm{D}$ maupun paparan sinar matahari yang mengandung sinar ultraviolet $\mathrm{B}$ yang rendah berperan dalam sintesis vitamin $\mathrm{D}$ di kulit. ${ }^{17,18}$ Desai $\mathrm{dkk}^{17}$ melaporkan bahwa asupan vitamin $\mathrm{D}$ yang rendah atau di bawah RDA serta paparan sinar UVB yang kurang menyebabkan sebagian besar (97\%) penderita TB mengalami insufisensi. Pada penelitian cross sectional yang dilakukan oleh Sari dkk, ${ }^{19}$ faktor yang paling memengaruhi rendahnya kadar vitamin D pada wanita di negara tropis seperti Indonesia adalah paparan sinar matahari, pekerjaan, dan asupan yang mengandung vitamin $\mathrm{D}$.

Sebagian besar anak $(94,7 \%)$ memiliki riwayat asupan vitamin D di bawah RDA, yaitu $<600$ IU. Penelitian Stellinga-Boelen $\mathrm{dkk}^{20}$ terhadap anak yang berasal dari Asia dan Afrika yang tinggal di Netherland juga menunjukkan hasil yang hampir sama, 94\% anak memiliki rerata asupan vitamin D $80 \%$ RDA berdasarkan food recall 1x24 jam. Sumber makanan yang mengandung vitamin $\mathrm{D}$ tidak banyak. Makanan yang mengandung vitamin $\mathrm{D}$, antara lain ikan, telur, susu dan produk olahan susu, margarin, dan makanan atau minuman yang difortifikasi dengan vitamin D. ${ }^{21-25}$ Pada penelitian kami, sumber asupan dengan kandungan vitamin $\mathrm{D}$ yang dikonsumsi oleh anak-anak, antara lain ikan laut, telur dan susu, serta multivitamin yang mengandung vitamin D. Terdapat beberapa anak yang mendapat multivitamin sirup yang 
mengandung vitamin $\mathrm{D}$, tetapi tetap tidak mencukupi kebutuhan vitamin $\mathrm{D}$ harian sesuai RDA.

Rerata asupan makanan yang mengandung vitamin D dan kadar vitamin D darah lebih tinggi pada anak perempuan dibanding anak laki-laki, tetapi secara statistik perbedaan tersebut tidak bermakna. Hal tersebut sesuai dengan penelitian Gray $\mathrm{dkk}^{26}$ yang melaporkan tidak ada perbedaan antara usia dan jenis kelamin terhadap kejadian rendahnya kadar vitamin $\mathrm{D}$ pada anak terinfeksi TB. Anak dengan status gizi baik memperoleh asupan vitamin D lebih besar dibanding anak dengan gizi kurang, tetapi tidak memiliki perbedaan statistik yang bermakna. Meskipun sebagian besar subjek penelitian memiliki status gizi baik, sebagian besar anak juga mengalami insufisiensi vitamin D.

Sebagian besar anak dengan asupan yang mengandung vitamin $\mathrm{D}$ di bawah RDA mengalami insufisiensi vitamin D (83,3\%), tetapi hubungan ini tidak bermakna secara statistik. Hal tersebut berbeda dengan penelitian sebelumnya yang melaporkan faktor asupan dan paparan sinar matahari berpengaruh terhadap kadar vitamin D dalam darah pada anak maupun dewasa. Perbedaan hasil tersebut dapat disebabkan oleh adanya perbedaan populasi, jumlah sampel, dan metode penilaian asupan nutrisi yang dipakai. Faktor lain yang mungkin berpengaruh adalah perbedaan waktu dan lamanya paparan sinar matahari serta pigmentasi kulit sehingga menghasilkan MED (minimal erythemal dose) yang berbeda pada tiap anak..$^{27,28}$ Selain itu, kemungkinan adanya polimorfisme genetik pada VDR (vitamin $D$ reseptor) dapat memengaruhi aktivitas vitamin $\mathrm{D}$ pada anak yang tetinfeksi TB. ${ }^{19}$

Dengan demikian, diperlukan penelitian dengan subjek yang lebih banyak dan food recall yang lebih lama, serta penelitian lanjutan berkaitan dengan asupan nutrisi yang mengandung vitamin D. Selain itu, perlu dilakukan penelitian lebih lanjut mengenai faktor lain seperti suplementasi vitamin D dan polimorfisme VDR yang memengaruhi kadar vitamin D darah pada anak yang terinfeksi TB.

\section{Daftar pustaka}

1. World Health Organization. Global Tuberculosis Report 2012. Geneva: WHO Press; 2012.

2. Kartasasmita CB. Epidemiologi tuberculosis. Sari Pediatri 2009;11:124-9.
3. Diani A. Proporsi infeksi tuberculosis dan faktor risiko pada balita yang tinggal dengan pasien tuberculosis dewasa. Sari Pediatri 2011;13:63-9.

4. Ahmed T, Sobhan F, Ahmed AMS, Banu S, Mahmood AM, Hyder KA, dkk. Childhood tuberculosis: a review of epidemiology, diagnosis and management. Pak J Infect Dis 2008; 17:52-9.

5. Chocano-Bedoya P, Ronnenberg AG. Vitamin D and Tuberculosis. Nutrition Rev 2009;67:289-93.

6. Nnoaham KE, Clarke A. Low serum vitamin D levels and tuberculosis: a systematic review and meta-analysis. Int J Epidemiol 2008;37:113-9.

7. Martineau AR. Vitamin D in the treatment and prevention of tuberculosis. Proceeding of Nutr Survey 2012;71:84-9.

8. Dini C, Bianchi A. The potential role of vitamin D for prevention and treatment of tuberculosis and infectious disease. Reviews. Ann Ist Super Sanita 2012;48:319-27.

9. Syafii AZ, Sukadi A, Setiabudiawan B. Association between plasma vitamin $\mathrm{D}$ level and tuberculosis in children. Paediatr Indones 2008;48:350-3.

10. Ganmaa D, Giovannucci E, Bloom BR, Fawzi W, Burr W, Batbaatar D, dkk. Vitamin D, tuberculin skin test conversion, and latent Tuberculosis in Mongolian school-age children: a randomized, double-blind, placebo-controlled feasibility trial. Am J Clin Nutr 2012;96:391-6.

11. Holick MF. Vitamin D deficiency. N Eng J Med 2007;357:266-81.

12. Holick MF. Sunlight, vitamin D and health : a D-lightful story. Dalam: Bjertness E, penyunting. Solar radiation and human healty. Oslo: The Norwegian Academy of Science and Letters; 2008.h.147-60.

13. Tornee S, Kaewkungwal J, Fungladda W, Silachamroon U, Akarasewi P, Sunakorn P. The association between environmental factors and tuberculosis infection among household contacts. Southeast Asian J Trop Med Public Health 2005;36:221-5.

14. Battersby A, Kampmann B, Burl S. Vitamin D in early childhood and the effect on immunity to Mycobacterium tuberculosis (Review). Clin Develop Immunol 2012:1-10.

15. Yamshchikov AV, Kurbatova EV, Kumari M, Blumberg HM, Ziegler TR, Ray SM. Vitamin D status and antimicrobial peptide cathelicidin (LL-37) concentrations in patients with active pulmonary tuberculosis. Am J Clin Nutr 2010;92:603-11.

16. Ralph AP, Lucas RM, Norval M. Vitamin D and solar ultraviolet radiation in the risk and treatment of tuberculosis (Review). Lancet Infect Dis 2013;13:77-88. 
17. Desai NS, Tukvadze N, Frediani JK, Kipiani M, Sanikidze E, Nichols MM, dkk. Effect of sunlight and diet on vitamin $\mathrm{D}$ status of pulmonary tuberculosis patients in Tbilisi, Goergia. Nutrition J 2012;4:362-6.

18. Haynes EN, Kalkwarf HJ, Hornung R, Wenstrup R, Lanphear BP. Vitamin D receptor fok I polymorfism and blood lead concentration in children. Environ Health Perspect 2003;13:1665-9.

19. Sari DK, Damanik HA, Lipoeto NI, Lubis Z. Is micro evaluation in tropical country women resulting low 25(OH)D level ?: a cross sectional study in Indonesia. J Nutr Food Sci 2013;4:1-7.

20. Stellinga-Boelen A, Wiegersma PA, Storm H, Bijleveld C, Verkade H. Vitamin D levels in children of asylum seekers in the Netherlands in relation to season and dietary intake. Eur J Pediatr 2007;166:201-6.

21. Vieth $\mathrm{R}$. The pharmacology of vitamin $\mathrm{D}$, including fortification strategies. Dalam: Feldman D, Glorieux F, penyunting. Vitamin D. Edisi ke-2. Canada: Elsevier; 2002.h.1-20.

22. Christakos S, Ajibade DV, Dhawan P, Fechner AJ, Mady LJ. Vitamin D : metabolism. Endocrinol Metab Clin North Am 2010;39:243-53.

23. Zhang R, Naughton D. Vitamin D in health and disease: current perspectives. Nutrition J 2010;9:1-13.

24. Lips P. Vitamin D physiology. J Pbiomolbio 2006;92:4-8.

25. Phillips F. The functions of vitamin D. Practice Nurs 2009;38:26-9.

26. Gray K, Wood N, Gunasekera H, Sheikh M, Hazelton $\mathrm{B}$, Isaacs D. Vitamin D and tuberculosis status in refugee children. Pediatr Infect Dis J 2012;13:521-3.

27. Webb AR. Who, what, where, and when-influence on cutaneus vitamin D synthesis. J Pbiomolbio 2006;92:1725.

28. Chen T, Chimeh F, Lu Z, Mathieu J, Person K, Zhang A, dkk. Factors that influence the cutaneous synthesis and dietary source of vitamin D. J Arch Biochem Biophys 2007;460:213-7. 